\title{
KONFLIK DAN INTEGRASI, SEBUAH KAJIAN AWAL: KASUS KERUSUHAN MEDAN, APRIL 1994
}

\author{
Wijaya K. Legowo
}

\begin{abstract}
Abstrak
Persoalan integrasi tidak bisa dipisahkan dengan masalah konflik. Konflik berkepanjangan dan mengalami eskalasi dapat melahirkan disintegrasi.Schermerhorn (1978) menguraikan integrasi ke dalam tiga model. Pertama, sebagai problem kebudayaan yang serasi. Kedua, sebagai pertentangan tujuan seperti subordinasi dari kelompok etnik terhadap superordinat dan ketiga, sebagai masalah legitimasi. Konflik berlatar etnisitas di masyarakat Indonesia, khususnya terkait etnis Tionghoa, ditemukan masih membekas dalam pikiran sebagian komunitas mereka yang ditemui di Jakarta. Kasus Medan (1994), Peristiwa Mei (1998) dan NTT (2012), memiliki esensi permasalahan yang sama, yakni masih adanya kebencian di tengah masyarakat di ketiga kasus tersebut. Upaya-upaya negara sejak Orde Baru sampai kini melalui seperangkat kebijakan (normatif) terbaca tidak koheren bagi terciptanya harmonisasi hubungan antaretnik. Penulis melakukan pendalaman langsung terhadap kasus kerusuhan di Medan, sementara peristiwa Mei terlihat dari Hongkong, dan kasus NTT terdengar di Jakarta. Bertolak dari pendalaman terhadap Kerusuhan Medan yang kemudian diproyeksikan pada Peristiwa Mei 1998 dan kasus NTT, secara mikroskopis, ditemukan adanya pola tertentu terkait masalah integrasi dan konflik, yaitu jarak hubungan yang terus menerus antara pemerintah dengan etnik Tionghoa adalah sebagai "legitimasi" salah satu penyebab terpeliharanya situasi konflik.
\end{abstract}

\section{Kata Kunci}

Integrasi, disintegrasi, legitimasi.

\begin{abstract}
Problems of integration cannot be separated from conflicts. They are two sides of the same coin. A long, escalating conflict may contribute to disintegration. Schermerhorn (1978) on his valuable book mentions there are three models of integration: first, the harmony of the cultural problems; second, the conflict between subordination of an ethnic group and the superordinates, and third, problems of legitimacy. We have found many ethnic conflicts in the Indonesia's plural society, especially the Chinese ethnic. The Indonesian Chinese minorities of Jakarta are still traumatized by and frightened of their memories for the Medan Riots (1994), the May Riots (1998) and the NTT incidents (2012), all of which are caused by the hatred feelings of majority towards the Indonesian Chinese ethnic.

Since the New Order Era, in order to come up with those problems, the government had issued numerous sets of regulations; however they had not fostered harmony of the ethnic relations within such plural society, particularly between the Indonesian Chinese ethnic and indigenous peoples in numerous regions. Based on the microscopic research on the Medan Riots, I have found a certain model problem of conflicts and integration : a certain relation between the Chinese ethnic and the bureaucracy has become one of the factors keeping the legitimation of conflicts.
\end{abstract}

\section{Keywords}

Integration, disintegration, legitimation. 


\section{KEADAAN UMUM KOTA MEDAN}

Medan yang menyandang status kota terbesar ketiga di Indonesia juga menghadapi persoalan warga pendatang yang tinggal dan hidup bersama dengan penduduk setempat (pribumi). Dengan demikian masyarakat Medan adalah masyarakat majemuk. Di antara penduduk pribumi yang terdiri dari beberapa suku dan para pendatang seperti WNI keturunan Cina dan keturunan asing lainnya, jumlah mayoritas penduduk setempat tidak memunculkan adanya kebudayaan dominan. Hasil penelitian Bruner di Kota Medan menyebutkan bahwa di berbagai arena sosial interaksi warganya secara bebas berkomunikasi dengan menggunakan identitas kesukuannya, tanpa adanya kontrol atau sanksi yang biasanya berasal dari suku lain yang mayoritas.

Dengan kuatnya identitas orang Cina yang tercermin dalam penggunaan bahasa Cina di arena-arena sosial seperti pasar, kantor-kantor swasta, hotel, pertokoan, sekolah, menjadi kuat pula pemisahan budaya dari kelompok suku lainnya. Ketika saya berkunjung ke kota ini, terasa sekali sikap spontanitas yang ditampilkan orangorang Batak dalam berkomunikasi, namun mereka tidak terlalu mencampuri persoalanpersoalan lain selama ini tidak disentuh.

Dalam arena sosial pendidikan tingkat dasar dan menengah dijumpai beberapa sekolah yang murid dan gurunya keturunan Cina dan menggunakan bahasa pengantar bahasa Cina. Dalam ketentuan sistem pendidikan nasional Indonesia, hal itu menyalahi ketentuan normatif. Namun, seperti biasa, tidak terdapat sanksi atau teguran dari kantor Pendidikan dan Kebudayaan setempat. Sementara karyawan administrasi dan guru yang direkrut dari kalangan suku Batak selama bertahun-tahun status kepegawaiannya bersifat kontrak yang dapat diperpanjang setiap tahun. Dengan demikian, tidak ada jaminan sosial seperti perumahan, kesehatan ataupun pendidikan, kecuali gaji pengajar dan uang transport untuk pergi bekerja. Menurut penelitian beberapa lembaga pendidikan swasta yang diwawancarai, sistem itu diterapkan atas perintah dan persetujuan lembaga pendidikan swasta sejenis yang berada di pusat (Jakarta).

Menurut Greif, masalah pembauran pendidikan (budaya) di luar Pulau jawa, termasuk Medan, sangat lambat dibanding yang terjadi di Jawa. Penduduk keturunan Cina menurut catatan tahun 1995 berjumlah 204.000 orang. Sedangkan di wilayah Pasar Baru (pemukiman pecinan di pusat kota Medan) warga keturunan Cina berjumlah 6.112 orang dan pribumi Batak 256 orang. Para tokoh informal warga keturunan Cina, baik yang tergabung dalam berbagai yayasan eksklusif (yayasan Marga dan lainnya) maupun yang duduk di dalam forum komunikasi bentukan pemerintah daerah setempat memiliki hubungan yang sangat dekat dengan pimpinan formal pemerintah. Kedekatan yang menyolok itu, misalnya adanya pengamanan tertentu dari aparat kekuasaan terhadap mereka yang kebanyakan pengusaha, menimbulkan kesan yang cenderung negatif di mata pribumi. Dengan demikian, forum komunikasi yang diharapkan menciptakan pemikiran-pemikiran untuk disumbangkan sebagai dasar 
kebijakan pembauran, dalam realisasinya tidak berjalan.

\section{KERUSUHAN 14-15 APRIL 1994}

Sekitar 20.000 buruh pada pagi 14 April 1994 berkumpul di lapangan Merdeka dan melakukan pawai menuju kantor Gubernur Sumatera Utara. Akibatnya, jalan-jalan macet dan mulai terjadi perusakan di pabrik-pabrik dan pusat pertokoan Cina di Medan. Perilaku anarkis itu, herannya tidak ditujukan kepada toko-toko milik pribumi atau orang kaya pribumi yang menggunakan mobil mewah. Toko-toko di Kecamatan Pasar Baru, pecinan Medan, ditutup untuk menghindari pawai dan lemparan batu dari massa.

Di samping warga Kelurahan Pasar Baru yang tercekam ketakutan untuk keluar rumah, para pemilik pabrik terpaksa meliburkan karyawannya selama beberapa hari. Kegiatan produksi praktis terhenti. Pabrik sumpit yang terletak di pinggiran kota Medan, yang menggaji karyawannya Rp 1.600,- per hari mengalami kerugian kerusakan bangunan akaibat lemparan batu karyawannya sendiri. Beberapa mobil direksi juga dirusak, sedangkan pemiliknya menyembunyikan diri di luar kota. Selama itu keamanan fisik dijaga oleh aparat keamanan. Kekerasan fisik, upah buruh dan keterlibatan aparat di pabrik sumpit itu hanya satu potret saja dari keadaan yang mirip dengan yang terjadi di PT. Juta Jelita dan banyak pabrik lain di sekitarnya. Kawasan ini dikenal dengan kawasan industri Medan yang pemiliknya WNI keturunan Cina.

Puncak kerusuhan sebenarnya hanya berlangsung dua hari. Namun, peristiwa singkat itu telah mengungkapkan kesadaran baik dari pemerintah, pengusaha, dan para buruh. Aksi-aksi kekerasan itu telah memancing pernyataan keprihatinan yang dikeluarkan Kedubes RRC di Jakarta sehubungan dengan masih banyaknya WNA RRC. Menlu RI Ali Alatas secara halus mengingatkan bahwa persoalan demo buruh adalah masalah dalam negeri dan pemerintah RI mampu menanganinya.

Perundang-undangan yang mengatur masalah perburuhan diimplementasikan melalui lembaga tripartit yang terdiri dari unsur pengusaha, Depnaker, dan buruh. Dalam perannya, Depnaker dapat membantu buruh, setidaknya memberikan solusi untuk kepentingan kedua belah pihak. Hubungan segi tiga ini idealnya seperti yang diuraikan Legg (1983) dimana pihak tuan yang memberikan status sosial yang mendatangkan pendapatan ekonomis berharap pula menerima kebaikan berupa tenaga atau jasa dari hambanya. Apabila hubungan ini tidak lancar barulah dibutuhkan adanya perantara yang berperan netral. Disinilah terjadi ironi kasus perburuhan di Medan. Dari tindakan dan pernyataannya di media massa, aparat Kanwil Depnaker lebih condong berpihak kepada pengusaha (Kompas 20 April dan 7 Mei 1994). Dari gambaran di atas terlihat adanya sikap yang membuat pengelompokan saling berhadapan antara pengusaha dan penguasa di satu sisi dengan buruh di sisi lain atau menurut Schermerhorn (1978) ada konflik sentripetal secara vertikal.

Di luar arena pabrik atau perusahaan yang sedang ramai tersebut, muncul 
solidaritas dari kelompok-kelompok yang memiliki perasaan sama dengan buruh yang sedang menuntut perbaikan nasib. Terbukti mereka berkumpul dan berjalan seiring seperti reaksi atas pernyataan-pernyataan baik dari pimpinan pabrik atau perusahaan maupun Pangab, Menko Polkam, dan Menaker yang menimbulkan kesan membela pengusaha. Menurut Schermerhorn (1978) pimpinan eksekutif pemerintah ini seolah-olah memiliki tanggung jawab ganda. Pertama menjadi pelindung dan kedua memanfaatkan pengusaha. Posisi ini perlu dianalisis sebagai suatu fenomena konflik sentrifugal dalam masyarakat yang sedang menuju proses integrasi.

Dengan demikian, konflik sebenarnya ada di arena perusahaan atau pabrikpabrik di Medan. Perusahaan atau pabrik yang merupakan arena-arena itu juga dapat dilihat sebagai struktur-struktur sosial dari struktur sosial lain di masyarakat. Ketika konflik terjadi di dalam struktur sosial (pabrik atau perusahaan) dan anggotanya pindah atau bergerak ke struktur sosial lain mereka kemudian akan mengelompok dengan anggota-anggota yang berlatar belakang "senasib-sepenanggungan" dan melancarkan aksinya terhadap sasaran-sasaran yang mereka anggap sebagai musuh.

Menurut berbagai sumber, jumlah yang ditangkap dalam peristiwa kerusuhan 62 orang, termasuk Ketua SBSI Medan dan Ketua Umumnya. Sedangkan korban pelemparan batu dan mati dipukul dalam mobinya sendiri bernama Kwok Joe Lip (50 tahun).

Pada dasarnya kerusuhan buruh ini bermula dari tuntutan para buruh atas perbaikan gajinya. Akan tetapi respon dari manajemen sangat tertutup dan menghindar serta cenderung berlindung di belakang aparat pemerintah. Dari media cetak diketahui bahwa dalam menanggapi tuntutan buruh, aparat justru menilai tuntutan kenaikan menjadi Rp 7.000,- itu tidak rasional dengan perbandingan gaji buruh di Jakarta hanya Rp 3.600,-. Sementara aparat yang mengurus keadaan buruh justru bertindak setengah-setengah. Ketika ditemukan 1.187 perusahaan (dari 6.942 yang diperiksa) melanggar ketentuan-ketentuan yang ada, hanya 17 perusahaan yang diajukan ke pengadilan. Informasi tentang hal ini terbuka dan diketahui umum serta para buruh yang pada gilirannya menyumbang terbentuknya prasangka adanya hubungan (guanxi) antara taoke dan penguasa, atau yang berpunya menerima pengayoman dibandingkan yang tidak berpunya. Menurut perhitungan Sri Tua Arif, gaji buruh Medan sebesar Rp. 1.600,- itu hanya cukup untuk transport buruh yang sehari-harinya menggunakan angkutan umum sebanyak dua kali. Sedangkan untuk kebutuhan dasar lain seperti perumahan dan makanan di rumah tidak cukup. Artinya, untuk kebutuhan fisik minimum (KFM) tidak mencukupi.

Besar dugaan para buruh tidak menyadari bahwa mereka hanya menjadi "alat produksi" dari pemilik perusahaan/pabrik, yang nasibnya berada di tangan majikan. Hubungannya pun ditentukan "boss", sehingga harapan-harapan atau keinginan pribadi buruh terpendam atau tertutup. Dalam konteks ini, posisi mereka terasa di bawah. Kedekatan hubungan aparat dan taoke serta jauhnya perlindungan yang diperlukan 
para buruh di pabrik-pabrik serta ekspose media mengenai kondisi ini telah memicu prasangka buruh dan mereka melampiaskan amarahnya ke para pengusaha yang kemudian meluas pada WNI keturunan Cina yang bermukim di luar pabrik-pabrik.

Dari pemberitaan media cetak dapat diketahui bahwa proses menuju aksiaksi perusakan bermula dari Ketua Umum SBSI, Mochtar Pakpahan pada Februari 1994 mengirim surat kepada Menaker. Isi suratnya antara lain meminta Menaker memperhatikan keadaan buruh Indonesia. Yang menarik adalah surat Ketua Umum SBSI tersebut dilampiri selebaran yang isinya mengajak buruh seluruh Indonesia untuk mogok selama satu jam sebelum mulai bekerja. Antara bulan Februari sampai dengan April 1994 Ketua SBSI Medan memperbanyak selebaran mengenai pemogokan yang diusulkan itu. Pada bulan-bulan itu media cetak baik yang berada di Jakarta maupun Medan juga sering memberitakan isu-isu yang berhubungan dengan SARA, yang tampak bermusuhan dengan etnik Cina.

Kerusuhan itu sendiri dapat diredam melalui penangkapan-penangkapan terhadap orang-orang yang dianggap aparat keamanan sebagai penggeraknya. Sementara melalui forum musyawarah segi tiga antara aparat teknis, pengusaha dan yang dianggap mewakili buruh (biasanya orang-orang ini ditunjuk oleh aparat sehingga tidak sepenuhnya mewakili kepentingan buruh). Dengan kecanggihan mekanisme komunikasi terhadap masyarakat melalui media cetak dan elektronik, kerusuhan berhenti. Akan tetapi tuntutan buruh masih dalam proses pengharapan dan penantian yang panjang.

\section{FAKTOR KONFLIK}

Seperti dijelaskan di muka, penelitian Bruner mengenai masyarakat kota Medan yang majemuk tidak menampakkan adanya kebudayaan dominan seperti di masyarakat Kota Bandung. Di Bandung, menurut Bruner, ada rasa tidak enak bila pendatang atau warga beretnik lain dari warga pribumi tidak mencoba menggunakan bahasa lokal dalam berkomunikasi di arena sosial umum. Di Medan, ungkapan komunikasi antaretnik berbeda berlangsung cukup bebas. Di pasar, sekolah, kantor swasta, bioskop, hotel dan tempat-tempat hiburan umum, orang-orang keturunan Cina secara bebas menggunakan bahasa Hokkian atau bahasa Mandarin. Dengan begitu, rasa kelompok-kelompok di dalam masyarakat semakin menebal. Penebalan rasa identitas dalam kelompok atau kuatnya segmen masyarakat ini menyebabkan semakin lebarnya jarak psikologi dan sosial antara orang Cina dan penduduk lokal.

Sementara itu, interaksi yang terjadi di arena sosial seperti pabrik dan perusahaan swasta di Medan yang dimiliki orang keturunan Cina dengan karyawan atau buruhnya yang umumnya penduduk lokal, dipengaruhi oleh manajemen gaya Cina. Seperti yang diungkap dalam penelitian Redding (1993), orang-orang Cina dalam mengendalikan perusahaannya menempatkan tenaga kerja dengan sistem familiisme di posisi-posisi 
kunci. Sistem ini tidak memungkinkan tenaga profesional di luar kerabat untuk menduduki jabatan-jabatan kunci tersebut. Aktivitas perusahaan yang dilakukan dalam administrasi dipengaruhi pula oleh rasa ketertutupan terhadap karyawan yang didasari atas kewaspadaan. Mengutip Redding, situasi seperti itu mendorong lahirnya rasa benci masyarakat atas kesuksesan yang diraih para pengusaha keturunan Cina.

Apabila dipikirkan secara dingin dan jernih, rasa benci di masyarakat umum itu tidak seluruhnya benar. Pendapat ini senada dengan ungkapan Ketua Sub Komisi Pemantauan HAM ketika kerusuhan di Medan terjadi. Praktek diskriminasi rasial dalam penggajian maupun promosi karyawan, terutama pada perusahaan swasta, telah lama menjadi pengetahuan masyarakat umum. Keadaan ini bertentangan dengan yang seharusnya dilakukan, yaitu setiap karyawan/buruh harus dilihat sesuai kemampauan dan prestasinya, bukan keturunannya atau agamanya, sebab ini menimbulkan ketidakadilan dan kecemburuan sosial.

Dalam kerusuhan di Medan, Direksi PT. GR menolak untuk berunding dengan buruh di pabrik yang ingin minta bertemua guna membicarakan kenaikan upah. Direksi memandang tuntutan Rp 7.000,- per hari tidak rasional. Jika memenuhi tuntutan buruh, perusahaan terpaksa akan menciutkan jumlah buruh. Karena posisi direksi berada di atas buruhnya, kekuatan berunding buruh sangat lemah.

\section{FAKTOR PEREDAM KONFLIK}

Geertz (dalam Saifuddin, 1986) mengungkapkan bahwa kelompok yang terlibat konflik sebenarnya saling berkaitan satu sama lain secara komplementer dan secara bersama berada dalam struktur sosial yang lebih luas. Kalau begitu, pada saat yang sama tercipta kondisi terintegrasi antara kelompok-kelompok tersebut dengan cara mengorganisasi dan mewujudkan simbol-simbol untuk mencapai tujuan bersama. Namun, hal ini tidak berarti batas-batas kelompok telah lebur dan digantikan oleh sebuah keadaan baru yang mengenal konflik (melting pot). Menurut saya, yang terjadi lebih cenderung adanya keadaan tumpang tindih struktur yang saling mengisi, melengkapi atau bahkan saling meniadakan.

Bagi masyarakat, tempat-tempat seperti pabrik atau perusahaan tentu bukan sekadar arena untuk kegiatan ekonomi, melainkan juga memiliki dimensi politik. Keduanya sulit dicari batas-batasnya. Emil Durkheim (dalam Saifudin, 1986) menyumbangkan pemikirannya mengenai diferensiasi pekerjaan dan spesialisasi serta dampaknya terhadap tatanan sosial masyarakat. Diferensiasi menjadi sebab dari ketergantungan manusia satu dengan lainnya karena tidak mampu lagi memenuhi kebutuhannya sendiri. Saling ketergantungan itu dapat pula diterjemahkan sebagai faktor integratif dalam masyarakat.

Dengan melihat secara langsung kondisi buruh, seperti yang diberitakan, keadaan ekonomi dan sosialnya memang memprihatinkan. Terlebih lagi mereka yang tidak bekerja dan tidak memiliki pendapatan. Dari sisi ini sudah tampak masalah 
lapangan pekerjaan sangat diperlukan oleh buruh. Secara lebih mendalam dapat dilihat bahwa pengangguran setiap tahun terus meningkat bersamaan dengan modernisasi pembangunan sosial ekonomi nasional yang tetap tidak mampu menyerap tenaga kerja yang rata-rata memiliki pendidikan sekolah dasar dan menengah (Kompas, 23/11/1995). Pembangunan sistem pendidikan dan kesejahteraan sosial masih tidak memungkinkan buruh untuk meningkatkan keterampilannya, apalagi mendapatkan waktu libur untuk rekreasi. Dalam posisi inilah aparat pemerintah dengan seluruh sistemnya bekerja dan sepatutnya menghindari cara-cara penekanan terhadap buruh.

Dari persidangan pemimpin kerusuhan Medan (Ketua dan Bendahara SBSI) diketahui sistem dan cara mengembalikan tenaga buruh untuk cepat bekerja kembali. Sistem ini memang dapat berjalan meski perbaikan masalah perburuhan yang disampaikan oleh orang-orang di luar pabrik masih menggantung.

\section{LEGITIMASI INTEGRASI}

Diskursus tentang Integrasi selalu mengait dengan konflik dan begitu pula sebaliknya. Situasi konflik umumnya berawal jika terdapat dua atau lebih entitas sosial beranggapan bahwa mereka memiliki suatu tujuan yang yang bertentangan stu sama lain. Sedangkan integrasi adalah sebuah proses dari unsur-unsur kelompok atau grup yang terorganisasi dan terkoordinasi dalam suatu aktifitas untuk mencapai tujuan bersama. Schermerhorn (1978) melihat integrasi sebagai tiga model. Pertama, sebagai problem kebudayaan yang serasi. Kedua, sebagai pertentangan tujuan seperti subordinasi dari kelompok etnik kepada superordinat, dan ketiga sebagai masalah legitimasi. Untuk kebutuhan elaborasi kasus Medan, model ketiga akan dibahas lebih jauh. Pertimbangannya, masalah ini tampak memiliki kaitan dengan soal-soal kekuasaan.

Berdasarkan kajian-kajian yang ada seperti Haryono (1993) yang mengkaji unsur kebudayaan Cina dan Jawa yang dipandang berkesesuaian, kurang mendukung topik tulisan ini. Sementara masalah integrasi yang kedua telah banyak diungkap baik dalam karya ilmiah maupun pemberitaan media massa. Kita juga telah seringkali mendengar pernyataan-pernyataan pimpinan pemerintah mengenai subordinasi etnik Cina ke dalam kebudayaan dominan atau mayoritas dengan alasan yang sama.

Legitimasi seperti dinyatakan Schermerhorn banyak didasarkan pada keseimbangan kekuasaan. Hal itu akan tampak bila dua kelompok atau grup yang memiliki sejarah budaya berbeda menjalin hubungan secara tetap. Dalam konteks ini, yang dimaksud dengan keseimbangan lebih pada keharusan untuk berkoordinasi. Tingkat sering tidaknya koordinasi dilakukan pengusaha memunculan variabel tingkattingkat legitimasi yang akhirnya melahirkan ketidakseimbangan pembagian hak-hak istimewa dan kewajiban-kewajiban yang dapat menimbulkan konflik.

Dalam menjelaskan konfigurasi antara dominan grup dan subordinat grup, Schermerhorn menempatkan kelompok mayoritas dan kelompok elite sebagai dominan 
grup. Sedangkan kelompok minoritas dan kelompok mengambang ditempatkan sebagai subordinat grup. Pembagian ini didasarkan pada criteria jumlah (size) dan kekuasaan (power). Contoh, sekelompok kecil orang bila memiliki pengaruh dan kekuasaan ia masuk dalam grup yang dominan.

Legitimasi bagi masing-masing kelompok dari perspektif hubungan kelompok dominan dan subordinat memunculkan 9 jenis kesatuan model integrasi seperti gambar berikut.

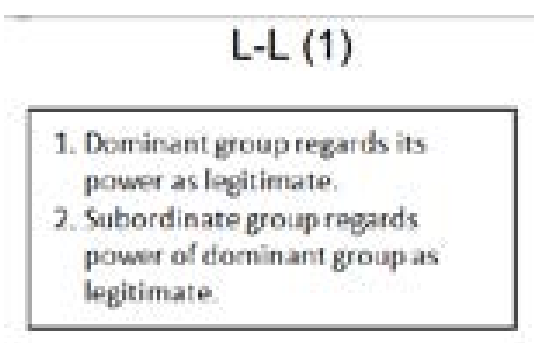

PL-L (4)

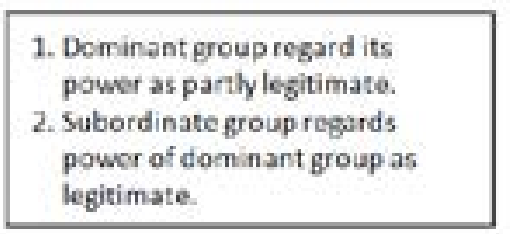

I-L (7)

1. Dominant group regards its power as illegitimate.

2. Subordinate group rigerds power of docninant group as legitimate

L-PL (2)

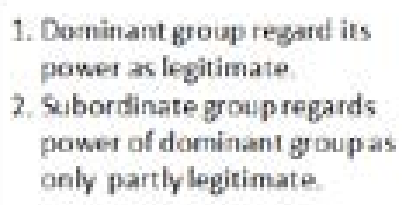

1. Dosninant group regard its power as legitimate

2. Subordinate group regards power of dorninant groupas anly partly legitimate.

PL-PL (5)

1. Dominant group regards its power as partlylegitimate. 2. Subordinate group regards power of dominant group as only partly legitimate.

I-PL (8)

1. Dominant group regards its power as illegirimate.

2. Subcrdinate group regards power of dominant groupas only partly legitimate
L-I (3)

1. Dominant group regard its power as legitimate

2. Subordinate group regards: power of dominant group as illegitimate.

$\mathrm{L}=$ Definition of superordination as legitimate

$\mathrm{PL}=$ Definition of superordination as partly legitimate

I = Definition of superordination as illegitimate

First letter $=$ self-definition of superordinate

Dari kesembilan kotak, tiga kotak $(7,8,9)$ sulit ditemukan dalam studi empirik. Sedangkan kotak nomor 4 agak meragukan sebab kelompok subordinat memiliki legitimasi melebihi superordinat. Sisanya menarik untuk diperhatikan. Dalam integrasi kotak 1 menunjukkan bentuk-bentuk yang stabil dengan mendasarkan pandangan konsensus-konsensus. Namun, bentuk ini masih jarang dijumpai di lapangan. Variabel kotak yang lain seperti nomor 2,3,4,5,6 hanya kesepkatan pandangan antara superordinat dan subordinat seperti tampak di kotak nomor 5 yang mewujudkan bentuk integrasi sosial di masyarakat. Dalam bentuk proses ini (PL-PL) benih-benih kompromistis muncul dikedua pihak untuk saling membuat akomodasi. Hanya saja, variabel tunggal dari kekuasaan dalam legitimasi, bentuk integrasinya kurang sempurna bila hanya 
berdasarkan saling kompromi. Bentuk ini juga tampak seperti kotak 2 (PL-PL). Kasus ini dapat dilihat terhadap para pendatang yang mensubordinasikan dengan cara pemaksaan untuk menerima tujuan asimilasi. Hal ini sama dengan proses pada kotak-kota 5,6 dan 3 . Berbeda sama sekali dengan kotak nomor 1 yang keduanya saling memiliki pandangan kesesuaian.

Model proses yang ideal tidak dapat dilihat dengan hanya membaca kotak satu per satu. Kotak satu dan lain, berdasar kondisi setempat, dipilih menjadi rangkaian yang berdasar integrasi ideal sebagai tujuannya. Untuk itu tampak harus dimulai dari kotak nomor 2 (L-PL) yang didorong secara kuat ke arah kotak nomor 1 (L-L) dengan proses melalui terlebih dahulu kotak nomor 5 (PL-PL).

Mengikuti jalan pikiran rumusan tersebut di atas, kasus kerusuhan Medan yang bermula dari hubungan pemilik pabrik (dominan) dan buruh (mengambang) dari dimensi legitimasi yang dipengaruhi kekuasaan pemerintah tampak berada di kotak nomor 2. Oleh karena itu masih dibutuhkan waktu lama adanya integrasi ideal dalam pabrik-pabrik atau perusahaan yang dimiliki warga keturunan Cina dengan karyawan pribumi sehingga memberikan kontribusi terhadap integrasi ideal di luar struktur sosal di tempat-tempat lainnya.

\section{KESIMPULAN}

Dalam hubungan lintas budaya dan di dalam budaya masyarakat Medan sendiri tidak ada kontrol dari budaya dominan. Hal itu menyebabkan menebalnya batas budaya maupun kelompok. Di arena sosial pabrik dan perusahaan tidak tersedia saluran-saluran politik-kalaupun ada, tidak berfungsi-bagi buruh sehingga mereka tidak berdaya menerima perlakuan tidak wajar mengenai penggajian. Ketidakberdayaan dalam struktur sosial ini ketika masuk ke dalam struktur sosial lainnya (SBSI) memperoleh pemberdayaan (melalui unjuk rasa) meskipun dalam konteks struktur sosial yang lebih besar (pemerintah) hal ini dianggap tidak legal.

Dalam memandang legalitas atau legitimasi sebagai upaya menjaga integrasi, legitimasi yang melekat dalam hubungan dan interaksi kekuasaan dengan kelompok elite pengusaha dan buruh atau kelompok mengambang, terdapat pelbagai alternative model integrasi. Betolak dari model yang ada, kerusuhan di Medan menggambarkan bahwa angggota masyarakat di arena perusahaan atau pabrik terintegrasikan dalam suatu komunitas industri yang keadaan ekonomi dan karyanya ditentukan dan tergantung sepenuhnya pada elite pengusaha melalui tipe manajemen tertentu. Sementara urusan keamanan kegiatan industri yang merupakan komitmen dari pembangunan nasional, sepenuhnya menjadi tanggung jawab unsur-unsur pemerintah. Semua keadaan itu telah menciptakan sistem untuk mempertahankan model integrasi di mana kelompok elite sepenuhnya memperoleh perlindungan dan kelompok mengambang hanya mendapatkan perlindungan setengah-setengah dari kekuasaan (L-PL). Integrasi seperti 
ini diyakini masih menyimpan potensi konflik yang besar.

\section{DAFTAR PUSTAKA}

\section{BUKU}

Brown, David. The State and Ethnic Politics in Southeast Asia. New York: Routledge. 1994.

Coppel, Charles A. Tionghoa Indonesia Dalam Krisis. Jakarta: Pustaka Sinar Harapan. 1994.

Cushman, Jennifer dan Wang Gungwu. Perubahan Identitas Orang Cina di Asia Tenggara. Jakarta: Pustaka Utama Grafiti. 1991.

Fredericik, Barth. Kelompok Etnik E Batasannya. Jakarta: UI Press. 1988.

Geertz, Clifford. Politik Kebudayaan. Yogyakarta: Penerbit Kanisius. 1992.

Hariyono, P. Kultur Cina dan Jawa. Jakarta: Pustaka Sinar Harapan. 1993.

Jahja, Junus. Nonpri di Mata Pribumi. Jakarta: Yayasan Tunas Bangsa. 1991.

Keith, Legg. Tuan Hamba \& Politisi. Jakarta: Sinar Harapan. 1983.

Ringer ,Benyamin B. dan Elimor R. Lowless. Race-Ethnicity and Society. New York: Routledge, Chapman \& Hall. Inc. 1989.

Saifudin, A. Konflik dan Integrasi. Jakarta: CV. Rajawali. 1986.

Schermerhorn. Comparative Ethnic Relations. Chicago: The University of Chicago Press. 1978.

Suryadinata, Leo. Dilema Minoritas Tionghoa. Jakarta: PT Grafiti Press. 1984.

Tan, Mely G. Golongan Etnis Tionghoa di Indonesia. Jakarta: PT Gramedia. 1981.

\section{KORAN}

Kompas, kliping bulan Februari sampai dengan November 1994. 